\title{
Effect of etoposide-induced alteration of the Mdm2-Rb signaling pathway on cellular senescence in A549 lung adenocarcinoma cells
}

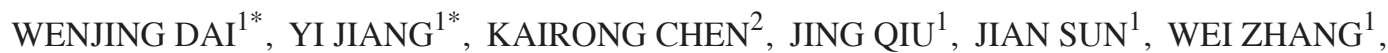 \\ XIAFEI ZHOU ${ }^{1}$, NA HUANG ${ }^{1}$, YUNHUI LI ${ }^{1}$ and WANCHENG LI ${ }^{1}$ \\ ${ }^{1}$ Department of Respiration, The First Affiliated Hospital of Chengdu Medical College, Chengdu, Sichuan 610500; \\ ${ }^{2}$ Department of Respiration, People's Hospital of Meishan, Meishan, Sichuan 620000, P.R. China
}

Received September 21, 2015; Accepted March 17, 2017

DOI: $10.3892 / \mathrm{ol} .2017 .6684$

\begin{abstract}
The present study aimed to investigate the effect of various concentrations of etoposide (VP-16) on the E3 ubiquitin-protein ligase $\mathrm{Mdm} 2(\mathrm{Mdm} 2)$-retinoblastoma $(\mathrm{Rb})$ signaling pathway in the cellular senescence of A549 lung adenocarcinoma cells. A549 cells were randomly divided into the following four groups: Control group (no treatment), group $1(1 \mu \mathrm{mol} / 1 \mathrm{VP}-16)$, group $2(5 \mu \mathrm{mol} / 1 \mathrm{VP}-16)$ and group 3 (25 $\mu \mathrm{mol} / 1 \mathrm{VP}-16)$. Each group was cultured for $48 \mathrm{~h}$ after treatment prior to observation of the alterations to cellular morphology. The cell cycle distribution of each group was also detected by flow cytometry. In addition, the activity of cellular senescence-associated $\beta$-galactosidase, and the expression of $\mathrm{Mdm} 2$ and phosphorylated (p-) $\mathrm{Rb}$ protein, was measured. The percentage of senescent cells was significantly higher following VP-16 treatment compared with the control group. The percentage of $\mathrm{G}_{1}$ phase cells, and $\mathrm{p}-\mathrm{Rb}$ protein and $\mathrm{Mdm} 2$ protein expression were also significantly different following VP-16 treatment compared with the control group. VP-16 increased the activity of $\beta$-galactosidase in the A459 cells. VP-16 also decreased the expression level of Mdm2 and $\mathrm{p}-\mathrm{Rb}$ protein and inhibited cell cycle progression in $\mathrm{G}_{1}$. These results indicate that VP-16 induces the cellular senescence of A549 cells via the Mdm2-Rb signaling pathway. However, further investigations are required to validate the mechanisms underlying these effects of VP-16.
\end{abstract}

Correspondence to: Dr Wancheng Li, Department of Respiration, The First Affiliated Hospital of Chengdu Medical College, 278 Baoguang Road, Chengdu, Sichuan 610500, P.R. China

E-mail:wcdoccn@163.com

*Contributed equally

Key words: etoposide, cellular senescence, Mdm2, retinoblastoma

\section{Introduction}

Lung cancer is a common primary pulmonary malignant tumor, with high incidence and mortality rates worldwide (1). In recent years, the incidence of lung cancer has increased annually and exhibited a trend towards those of younger ages (1). The 5-year survival rate of lung cancer in China is only $10 \%$, since the majority of patients have mid-late stage lung cancer or are no longer eligible for surgery at the time of diagnosis (2). The typical chemotherapeutic approach for lung cancer is to inhibit DNA replication or metabolic enzymes, thus interfering with cell division (3); however, the side effects of these treatments mean that patients do not tolerate them well. Furthermore, the intermittent period between these treatments is long, which may lead to disease recurrence and drug resistance (4). Therefore, it is necessary to develop novel therapeutic strategies for the treatment of lung cancer. Previous studies have suggested that a low-dose and high frequency/long duration of treatment with certain chemotherapeutic drugs may induce cellular senescence, improving the patient's quality of life and prolonging survival; this chemotherapy is called continuous low-dose chemotherapy (LDM) $(5,6)$.

Compared with traditional chemotherapy, LDM has several advantages, including a lower toxicity, lower cost and shorter required intermittent period. This may reduce disease recurrence and drug resistance, in addition to making it easier for patients to receive and accept long-term treatment, thus improving their quality of life and prolonging survival $(7,8)$. However, the mechanism underlying the effects of LDM remains unclear.Induction of cellular senescence may inhibit the cell cycle in $G_{1}$ phase (9).

Cellular senescence refers to the transition of a cell from an active growing state to an irreversible growth arrest state $(10,11)$. It was previously demonstrated that senile cells primarily contained $G_{1}$ phase DNA, suggesting that they were arrested in $G_{1}(12)$. Activation of the retinoblastoma $(\mathrm{Rb})$ protein is associated with $\mathrm{G}_{1}$ phase cell cycle arrest. It has previously been revealed that negative feedback regulation of the E3 ubiquitin-protein ligase $\mathrm{Mdm} 2(\mathrm{Mdm} 2)-\mathrm{Rb}$ signaling pathway serves a role in tumorigenesis $(13,14)$. 
Etoposide (VP-16) is as an antitumor drug that specifically targets the cell cycle (15). The present study investigated the effect of various concentrations (1-25 $\mu \mathrm{mol} / \mathrm{l})$ of VP-16 on the Mdm2-Rb signaling pathway and cellular senescence in A549 lung adenocarcinoma cells.

\section{Materials and methods}

Cell culture. The A549 lung cancer cell line was obtained from the Cancer Laboratory of the First Affiliated Hospital of Chengdu Medical College (Chengdu, China). A549 cells were cultured in RPMI-1640 medium supplemented with $10 \%$ fetal bovine serum (Gibco; Thermo Fisher Scientific, Inc., Waltham, MA, USA) at $37^{\circ} \mathrm{C}$ with $5 \% \mathrm{CO}_{2}$ and saturated humidity. Cells in the logarithmic phase were digested using $0.25 \%$ trypsin (Fuzhou Maixin Biotechnology Development Co., Ltd., Fuzhou, China) for 2-3 min and then the cell suspension was obtained.

Observation of cell morphology and cell cycle analysis. A549 cells in the logarithmic phase of growth were seeded into 6-well plates $\left(2 \times 10^{5} /\right.$ well $)$ and cultured at $37^{\circ} \mathrm{C}$ for $24 \mathrm{~h}$. Subsequently, 0 (control group), 1 (group 1), 5 (group 2) and 25 (group 3) $\mu \mathrm{mol} / 1$ VP-16 (Jiangsu Hengrui Medicine Co., Ltd., Lianyungang, China) was added and the cells were cultured for a further $48 \mathrm{~h}$. The cells were then placed under an inverted microscope. Six fields of view were randomly selected for observation and determination of cell morphologies. The cell cycle distribution was detected by flow cytometry using a FACSCalibur flow cytometer with BD FACStation software (ImagePro-Plus v6.0) (both BD Biosciences, Franklin Lakes, NJ, USA).

Detection of senescence. Prior to cell seeding, 6-well plates were placed on a sterilized tray and $1 \times 10^{5}$ cells were added to each well. Then the 6-well plates were covered with plastic film, and the cells were cultured overnight at $37^{\circ} \mathrm{C}$. Various concentrations $(0,1,5$ and $25 \mu \mathrm{mol} / \mathrm{l})$ of VP-16 were added to the culture medium, followed by culture at $37^{\circ} \mathrm{C}$ for $48 \mathrm{~h}$. One $\mathrm{ml}$ of senescence-associated $\beta$-galactosidase fixation fluid (Beyotime Institute of Biotechnology, Haimen, China) was added, followed by incubation at room temperature for $15 \mathrm{~min}$. The senescence-associated $\beta$-galactosidase was detected using a previously described method (16) and was used to calculate the percentage of senescent cells in each treatment group.

The use of $\mathrm{X}$-Gal as a substrate for the $\beta$-galactosidase enzyme generates deep blue colored products, thus senile cells were defined as those with blue granules when observed under a DVM6 optical microscope (Leica Microsystems $\mathrm{GmbH}$, Wetzlar, Germany).

Immunocytochemistry. Prior to cell seeding, the 6-well plates were placed on a sterilized tray and $1 \times 10^{5}$ cells were added to each well. The cells were then cultured overnight at $37^{\circ} \mathrm{C}$. Subsequently, 0, 1, 5 and $25 \mu \mathrm{mol} / 1 \mathrm{VP}-16$ were added to the culture medium and the cells were cultured for a further $48 \mathrm{~h}$ culture at $37^{\circ} \mathrm{C}$. Cells were incubated overnight at $4^{\circ} \mathrm{C}$ with the following primary antibodies: Polyclonal rabbit anti-human Mdm2 antibody (catalogue number PAB27165; dilution 1:200;
Table I. Effect of VP-16 on the cell cycle distribution of A549 cells.

\begin{tabular}{lccr}
\hline & \multicolumn{3}{c}{ Percentage of cells } \\
\cline { 2 - 4 } Group & $\mathrm{G}_{1}$ & $\mathrm{~S}$ & \multicolumn{1}{c}{$\mathrm{G}_{2}$} \\
\hline Control & $56.70 \pm 1.17$ & $32.51 \pm 2.52$ & $11.01 \pm 1.25$ \\
Group 1 & $60.91 \pm 0.26$ & $29.21 \pm 1.71$ & $9.83 \pm 0.78$ \\
Group 2 & $77.35 \pm 2.32^{\mathrm{a}}$ & $12.31 \pm 2.79^{\mathrm{a}}$ & $10.31 \pm 0.76$ \\
Group 3 & $46.17 \pm 2.73^{\mathrm{a}}$ & $43.11 \pm 2.28^{\mathrm{a}}$ & $10.71 \pm 0.88$
\end{tabular}

${ }^{\mathrm{a}} \mathrm{P}<0.05$ vs. the control group.

Abzoom Biolabs, Inc., Dallas, TX, USA), polyclonal rabbit anti-human $\mathrm{p}-\mathrm{Rb}$ antibody (catalogue number FZ200784; dilution 1:100; Shanghai Fuzhong Biological Science Co., Ltd., Shanghai, China). After adding polymer enhancer and PBS washing, $50 \mu 1$ of goat anti-rabbit IgG horseradish peroxidase-labeled secondary antibody (catalogue number 150077; dilution 1:200; Abcam, Cambridge, USA) was drop wisely added to each section, followed by incubation at $37^{\circ} \mathrm{C}$ for 30 min and PBS washing for 3 times. Following coloration, counterstain and mounting, the sections were observed using a Q550CW image acquisition and analysis system (Leica Microsystems $\mathrm{GmbH}$ ).

Statistical analysis. Results are expressed as the mean \pm standard deviation. One-way analysis of variance was performed using SPSS software (version 19.0; SPSS, Inc., Chicago, IL, USA). $\mathrm{P}<0.05$ was considered to indicate a statistically significant difference.

\section{Results}

Cell morphology changes. Prior to treatment with VP-16, the number of cells and cell morphology of the control and experimental groups was similar. Following a $48 \mathrm{~h}$ treatment with VP-16 (Fig. 1), the control group cells grew with uniform sizes and shapes (Fig. 1A), whereas group 2 demonstrated significantly decreased cell numbers and irregular morphology, including increased cell volumes, pseudopodia, large nuclei, reduced cytoplasm and intracytoplasmic vacuoles (Fig. 1C). Groups 1 and 3 demonstrated no notable changes in cellular morphology (Fig. 1B and D, respectively).

VP-16 alters the cycle distribution of A549 cells. The results of flow cytometry analysis demonstrated that, compared with the control group, in group 2 the percentage of cells in $\mathrm{G}_{1}$ phase was significantly increased and the percentage of cells in $\mathrm{S}$ phase was significantly decreased (both $\mathrm{P}<0.05$; Table I). In group 3, the percentage of cells in the $G_{1}$ was significantly decreased and the percentage of cells in $\mathrm{S}$ phase was significantly increased $(\mathrm{P}<0.05$; Table I). There as no significant differences between the percentage of cells in $\mathrm{G}_{1}$ or $\mathrm{S}$ phases between group 1 and the control group, and no significant difference in the percentage of cells in $G_{2}$ phase was revealed between the four groups (Table I). 
Table II. Effect of VP-16 on the senescence of A549 cells.

\begin{tabular}{lc}
\hline Group & Percentage of senescent cells \\
\hline Control & $1.41 \pm 1.06$ \\
Group 1 & $11.03 \pm 1.82^{\mathrm{a}}$ \\
Group 2 & $79.11 \pm 6.09^{\mathrm{a}, \mathrm{b}}$ \\
Group 3 & $5.62 \pm 1.16^{\mathrm{a}-\mathrm{c}}$ \\
\hline
\end{tabular}

${ }^{\mathrm{a}} \mathrm{P}<0.05$ vs. control group; ${ }^{\mathrm{b}} \mathrm{P}<0.05$ vs. group 1 ; ${ }^{\mathrm{c}} \mathrm{P}<0.05$ vs. group 2 .

Table III. Effect of VP-16 on the expression of Mdm2 protein in A549 cells.

\section{Group}

Percentage of Mdm2 protein-positive cells

$\begin{array}{ll}\text { Group } & 90.18 \pm 2.38 \\ \text { Group 1 } & 87.03 \pm 3.86 \\ \text { Group 2 } & 65.60 \pm 6.81^{\mathrm{a}-\mathrm{c}} \\ \text { Group 3 } & 86.50 \pm 4.01\end{array}$

${ }^{\mathrm{a}} \mathrm{P}<0.05$ vs. the control group; ${ }^{\mathrm{b}} \mathrm{P}<0.05$ vs. group $1 ;{ }^{\mathrm{c}} \mathrm{P}<0.05$ vs. group 3. Mdm2, E3 ubiquitin-protein ligase Mdm2.

Table IV. Effect of VP-16 on the expression of phosphorylated $\mathrm{Rb}$ protein in A549 cells.

\begin{tabular}{lc}
\hline Group & $\begin{array}{c}\text { Percentage of phosphorylated } \\
\text { Rb protein-positive cells }\end{array}$ \\
\hline Control & $90.23 \pm 2.24$ \\
Group 1 & $86.51 \pm 3.43$ \\
Group 2 & $59.12 \pm 7.66^{\mathrm{a}-\mathrm{c}}$ \\
Group 3 & $86.15 \pm 13.51^{\mathrm{c}}$
\end{tabular}

${ }^{\mathrm{a}} \mathrm{P}<0.05$ vs. control group; ${ }^{\mathrm{b}} \mathrm{P}<0.05$ vs. group 1 ; ${ }^{\mathrm{c}} \mathrm{P}<0.05$ vs. group 3 . $\mathrm{Rb}$, retinoblastoma.

VP-1 effects the senescence of A549 cells. Detection of senescence-associated $\beta$-galactosidase is an important staining method that can be used to effectively detect senile cells. The lysosome contents of senile cells are increased, which induces an increased expression of the lysosomal enzyme $\beta$-galactosidase. Following treatment with 1,5 or $25 \mu \mathrm{mol} / 1$ VP-16 for $48 \mathrm{~h}$, the cells contained blue particles (Fig. 2), indicating that VP-16 induces the senescence of A549 cells. Group 2 has the highest level of the staining, whereas that in groups 1 and 3 was not as high (Table II). The percentage of senescent cells between the control group and experimental groups, in addition to the comparisons between the experimental groups, were significantly different $(\mathrm{P}<0.05$; Table II).

Impact of VP-16 treatment on Mdm2 protein expression. $\mathrm{Mdm} 2$ protein was primarily expressed as brownish-yellow/tan particles in the cytoplasm and nuclei of A549 cells (Fig. 3). Following treatment with various concentrations of VP-16 ( 0 , 1,5 and $25 \mu \mathrm{mol} / \mathrm{l}$ ) for $48 \mathrm{~h}$, group 2 exhibited significantly decreased expression of Mdm2 protein compared with the control group and groups 1 and 3 ( $\mathrm{P}<0.05$; Table III). The differences in the expression of Mdm 2 between the control group and groups 1 and 3 were not significant, and the difference between groups 1 and 3 was also not significantly different (Table III).

Effect of VP-16 on the expression of $p-R b$ protein. The $\mathrm{Rb}$ protein was primarily identified as a nuclear phosphoprotein inside the nuclei of the A549 cells (Fig. 4). Following treatment with various concentrations of VP-16 $(0,1,5$ and $25 \mu \mathrm{mol} / \mathrm{l})$ for $48 \mathrm{~h}$, group 2 exhibited a significantly decreased expression $\mathrm{p}-\mathrm{Rb}$ protein compared with the control group and groups 1 and $3(\mathrm{P}<0.05)$, whereas the differences between the control group and experimental groups 1 and 3 was not significantly different (Table IV). The difference between groups 1 and 3 was also not significantly different (Table IV).

\section{Discussion}

During the 1960 s, Hayflick et al (17) demonstrated in a fibroblast culture that normal diploid cells would enter a state of senescence when proliferated for the 50-70th generation in vitro. No further subculture could continue while the cells remained in senescence; this phenomenon was named the 'Hayflick limit'. A previous study (18) revealed that cellular senescence is the third most important cancer prevention process, following cell DNA repairing and apoptosis; therefore, it is closely associated with the occurrence, development and treatment strategy for tumors.

It has been demonstrated that senile cells primarily contain $\mathrm{G}_{1}$ phase DNA, thus it was considered that the senile cells were arrested in phase $G_{1}$ and were not able to enter phase $\mathrm{S}$ successfully (19). The Mdm2-Rb signaling pathway may induce the arrest the cell in $\mathrm{G}_{1}$, which can result in cellular senescence (20). A low-concentration of VP-16 may also induce cellular senescence. A low-concentration VP-16 acts on the Mdm2-Rb signaling pathway, increasing the expression of $\mathrm{Rb}$ protein, decreasing the phosphorylation of $\mathrm{Rb}$ and decreasing the expression of Mdm2, thus promoting the senescence of tumor cells (21). Cellular senescence has various characteristics, including the generation of long pseudopodia and increased $\beta$-galactosidase activity $(22,23)$.

If normal cells did not undergo senescence, it would result in the development of tumors; therefore, inducing tumor cell senescence has become a focus for studies investigating treatments for cancer. Previous studies have demonstrated that appropriate concentrations of DNA replication inhibitor agents, including Adriamycin (24-26), aphidicolin and cisplatin (27) may induce the phenotypes of cellular senescence. Furthermore, ionizing radiation, cytarabine, etoposide, paclitaxel, vincristine, hydroxyurea $(28,29)$, camptothecin (30) and bromodeoxyuridine $(31,32)$ may also be able to induce senescence. The most extensively researched agent is Adriamycin, a topoisomerase inhibitor. Elmore et al (33) reported that among 14 cell lines derived from solid human tumors, adriamycin induced senescent phenotypes in 11 cell lines, 

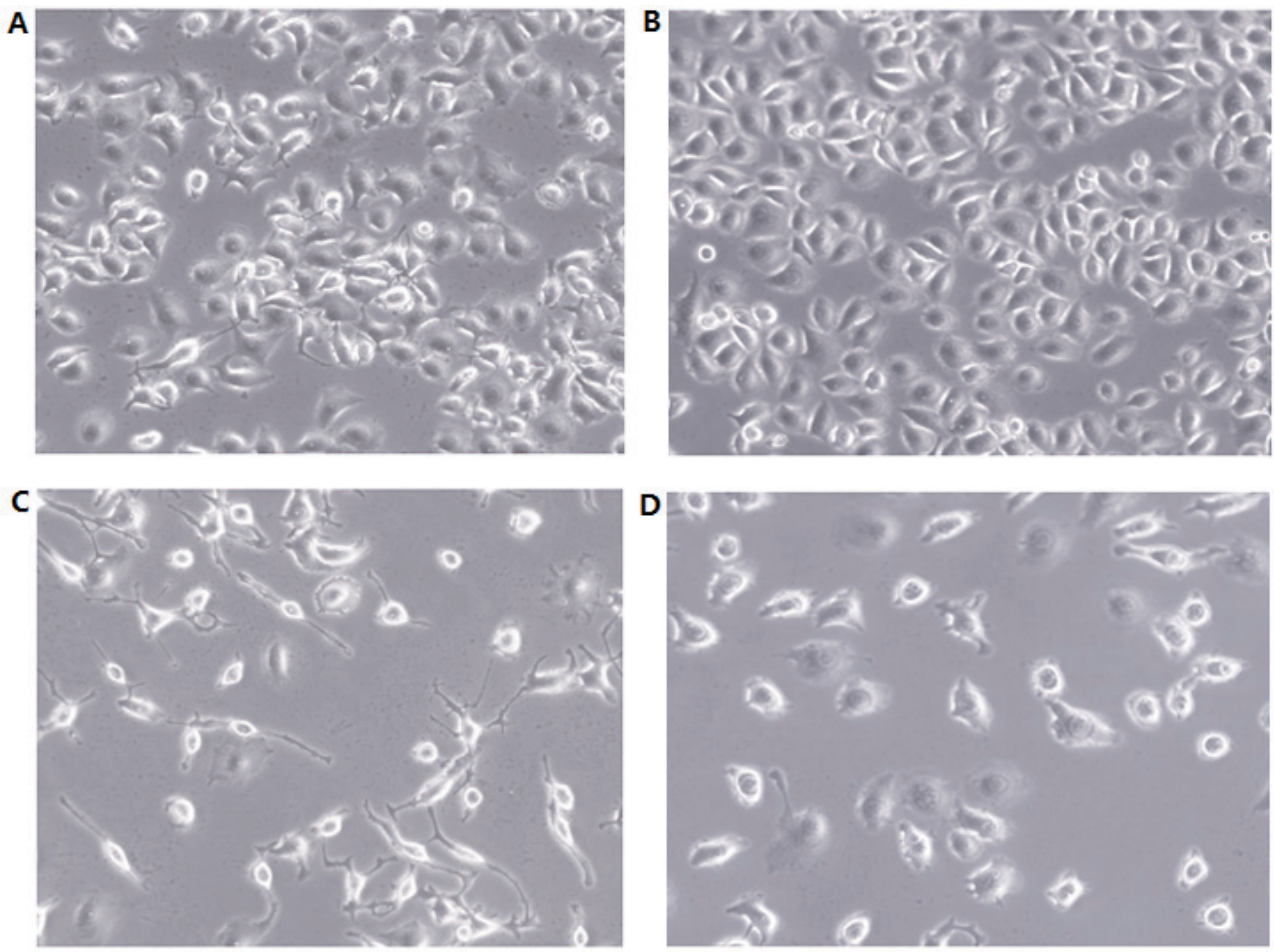

Figure 1. VP-16 alters the morphology of A549 cells. (A) Control group (no treatment). (B) Group 1 (1 $\mu \mathrm{mol} / 1$ VP-16). (C) Group 2 (5 $\mu$ mol/1 VP-16). (D) Group $3(25 \mu \mathrm{mol} / 1 \mathrm{VP}-16)$. Magnification, x200.
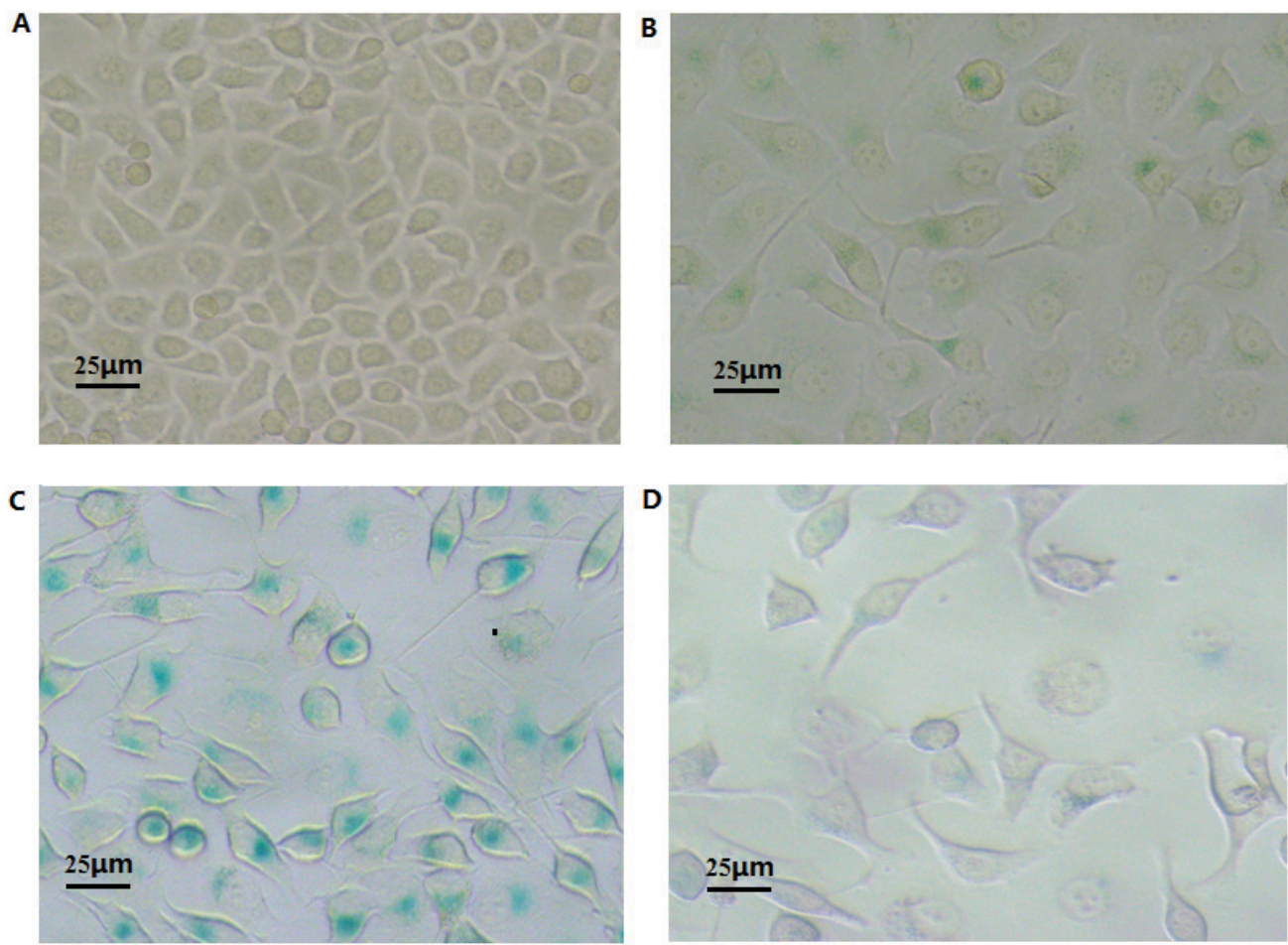

Figure 2. VP-16 affects the senescence of A549 cells. (A) Control group (no treatment). (B) Group 1 (1 $\mu \mathrm{mol} / 1 \mathrm{VP}-16)$. (C) Group 2 (5 $\mu \mathrm{mol} / 1$ VP-16). (D) Group 3 (25 $\mu \mathrm{mol} / 1 \mathrm{VP}-16)$. Magnification, $\mathrm{x} 400$.

and it was confirmed that the drug-induced senescent phenotypes were not associated with the shortening of telomeres, so could not be inhibited by the overexpression of telomerase. However, in certain cell lines, Adriamycin was not able to induce the characteristics of cellular senescence; therefore, it was suggested that the cellular senescence of tumor cells may occur spontaneously or be associated with the cellular microenvironment (24). Drug-induced cellular senescence has been identified to be associated with p21, p16 and cellular tumor antigen p53 (p53) (34). 
A

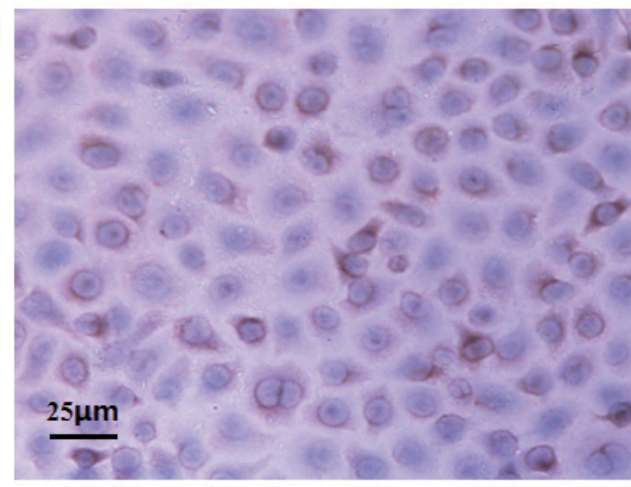

C

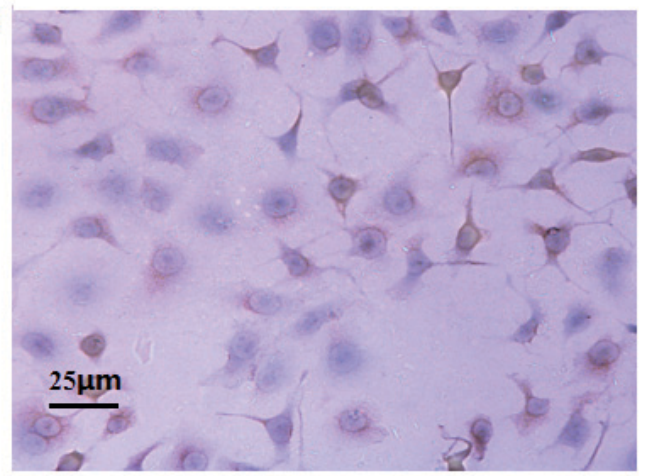

B

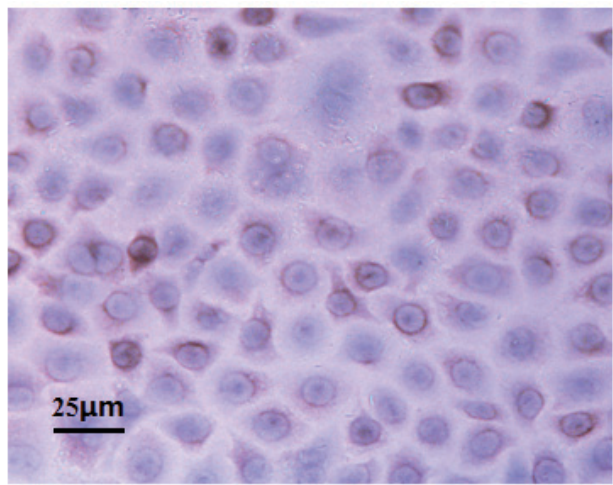

D

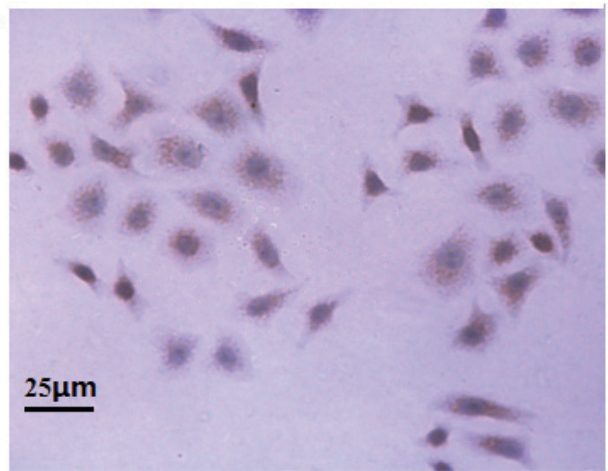

Figure 3. Effect of VP-16 on the expression of Mdm2 protein in A549 cells. (A) Control group (no treatment). (B) Group 1 (1 $\mu$ mol/1 VP-16). (C) Group 2 (5 $\mu \mathrm{mol} / 1$ VP-16). (D) Group 3 (25 $\mu \mathrm{mol} / 1 \mathrm{VP}-16)$. Magnification, x400.
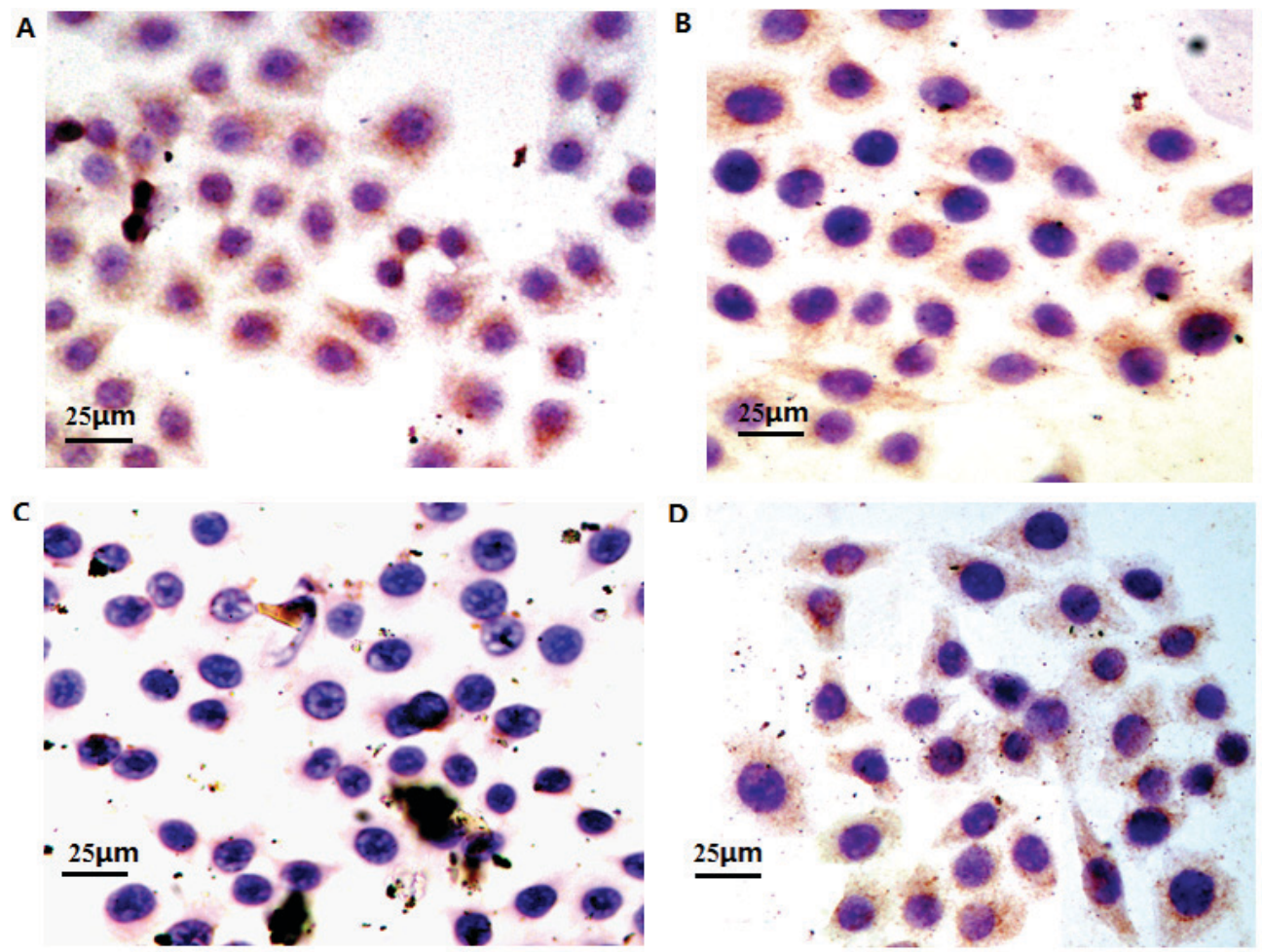

Figure 4. Effect of VP-16 on the expression of phosphorylated Rb protein in A549 cells. (A) Control group (no treatment). (B) Group 1 (1 $\mu$ mol/1 VP-16). (C) Group 2 (5 $\mu \mathrm{mol} / 1 \mathrm{VP}-16)$. (D) Group 3 (25 $\mu \mathrm{mol} / 1 \mathrm{VP}-16)$. Magnification, x400.

VP-16 is a cell cycle-specific antitumor drug that inhibits cells in the $\mathrm{S} / \mathrm{G}_{2}$ phase. VP-16 acts on DNA topoisomerase II, forming a stable drug-enzyme-DNA complex, thus interfering with DNA repairing (35). Therefore, the present study used 1,5 and $25 \mu \mathrm{mol} / 1$ of VP-16 for $48 \mathrm{~h}$ treatments. The results demonstrated that $5 \mu \mathrm{mol} / 1 \mathrm{VP}-16$ significantly induced 
cellular senescence of A549 cells, $1 \mu \mathrm{mol} / 1$ only slightly induced cellular senescence and $25 \mu \mathrm{mol} / 1 \mathrm{VP}-16$ did not significantly induce cellular senescence. This suggests that a very specific concentration of VP-16 is required to induce cellular senescence in A549 cells. Therefore, the optimal concentration of VP-16 that induced cellular senescence in A549 cells was $5 \mu \mathrm{mol} / 1$.

When treated with $5 \mu \mathrm{mol} / 1 \mathrm{VP}-16, \mathrm{p}-\mathrm{Rb}$ and $\mathrm{Mdm} 2$ protein expression was significantly reduced in the A549 cells, whereas no obvious change was observed when 1 and $25 \mu \mathrm{mol} / 1$ treatments were administered. This indicates that low-concentration treatments of VP-16 reduced the levels of $\mathrm{p}-\mathrm{Rb}$ protein, resulting in the release of transcription factor E2F, which prevents cell cycle progression and downregulates the expression of Mdm2, and thus its binding to p53 and Rb.

In conclusion, low-concentration treatments of VP-16 may effect the Mdm2-Rb signaling pathway, reducing the expression of $\mathrm{Mdm} 2$ protein and thus its binding to $\mathrm{Rb}$. Therefore, non-phosphorylated $\mathrm{Rb}$ protein expression was increased, whereas the $\mathrm{p}-\mathrm{Rb}$ protein expression was reduced, increasing the amount of functional $\mathrm{Rb}$ and resulting in the induction of cellular senescence. However, as this is a preliminary study, future investigations are required to further reveal the mechanisms underlying the effects of VP-16.

\section{References}

1. Torre LA, Siegel RL, Ward EM and Jemal A: Global cancer incidence and mortality rates and trends-an update. Cancer Epidemiol Biomarkers Prev 25: 16-27, 2016.

2. Yang J, Zhu J, Zhang YH, Chen YS, Ding LL, Kensler TW and Chen JG: Lung cancer in a rural area of china: Rapid rise in incidence and poor improvement in survival. Asian Pac J Cancer Prev 16: 7295-7302, 2015

3. Rosell R, Pifarré A, Monzó M, Astudillo J, López-Cabrerizo MP, Calvo R, Moreno I, Sanchez-Céspedes M, Font A and Navas-Palacios JJ: Reduced survival in patients with stage-I non-small-cell lung cancer associated with DNA-replication errors. Int J Cancer 74: 330-334, 1997.

4. Crane EJ and Simon G: Adjuvant chemotherapy for non-small cell lung cancer. Curr Treat Options Oncol 7: 51-58, 2006.

5. Schiller JH, Harrington D, Belani CP, Langer C, Sandler A, Krook J, Zhu J and Johnson DH; Eastern Cooperative Oncology Group: Comparison of four chemotherapy regimens for advanced non small-cell lung cancer. N Eng J Med 346: 92-98, 2002.

6. Loven D, Hasnis E, Bertolini F and Shaked Y: Low-dose metronomic chemotherapy: From past experience to new paradigms in the treatment of cancer. Drug Discov Today 18: 193-201, 2013.

7. Seng JE and Peterson BA: Low dose chemotherapy for myelodysplastic syndromes. Leuk Res 22: 481-484, 1998.

8. Bello L, Carrabba G, Giussani C, Lucini V, Cerutti F, Scaglione F, Landré J, Pluderi M, Tomei G, Villani R, et al: Low-dose chemotherapy combined with an antiangiogenic drug reduces human glioma growth in vivo. Cancer Res 61: 7501-7506, 2001.

9. Di Micco R, Fumagalli M, Cicalese A, Piccinin S, Gasparini P, Luise C, Schurra C, Garre' M, Nuciforo PG, Bensimon A, et al: Oncogene-in-duced senescence is a DNA damage response triggered by DNA hyperreplication. Nature 444: 638-642, 2006.

10. Banito A and Lowe SW: A new development in senescence. Cell 155: 977-978, 2013.

11. Collado M, Blasco MA and Serrano M: Cellular senescence in cancer and aging. Cell 130: 223-233, 2007.

12. Hornsby PJ: Senescence as an anticancer mechanism. J Clin Oncol 25: 1852-1857, 2007.

13. Ryan BM, Calhoun KM, Pine SR, Bowman ED, Robles AI, Ambs S and Harris CC: MDM2 SNP285 does not antagonize the effect of SNP309 in lung cancer. Int J Cancer 131: 2710-2716, 2012.
14. Tang YA, Lin RK, Tsai YT, Hsu HS, Yang YC, Chen CY and Wang YC: MDM2 overexpression deregulates the transcriptional control of RB/E2F leading to DNA methyltransferase 3A overexpression in lung cancer. Clin Cancer Res 18: 4325-4333, 2012.

15. Yan J and Tang D: Prostate cancer stem-like cells proliferate slowly and resist etoposide-induced cytotoxicity via enhancing DNA damage response. Exp Cell Res 328: 132-142, 2014.

16. Itahana K, Itahana $Y$ and Dimri GP: Colorimetric detection of senescence-associated $\beta$ galactosidase. Methods Mol Biol 965: 143-156, 2013.

17. Hayflick L and Moorhead PS: The serial cultivation of human diploid cell strains. Exp Cell Res 25: 585-621, 1961.

18. Tchkonia T, Zhu Y, van Deursen J, Campisi J and Kirkland JL: Cellular senescence and the senescent secretory phenotype: Therapeutic opportunities. J Clin Invest 123: 966-972, 2013.

19. Mao Z, Ke Z, Gorbunova V and Seluanov A: Replicatively senescent cells are arrested in G1 and G2 phases. Aging (Albany NY) 4: 431-435, 2012.

20. Huna A, Salmina K, Erenpreisa J, Vazquez-Martin A, Krigerts J, Inashkina I, Gerashchenko BI, Townsend PA, Cragg MS and Jackson TR: Role of stress-activated OCT4A in the cell fate decisions of embryonal carcinoma cells treated with etoposide. Cell Cycle 14: 2969-2984, 2015.

21. Yap DB, Hsieh JK, Chan FS and Lu X: Mdm2: A bridge over the two tumour suppressors, p53 and Rb. Oncogene 18: 7681-7689, 1999.

22. Seviour EG, Sehgal V, Lu Y, Luo Z, Moss T, Zhang F, Hill SM, Liu W, Maiti SN, Cooper L, et al: Functional proteomics identifies miRNAs to target a $27 / \mathrm{Myc} /$ phospho-Rb signature in breast and ovarian cancer. Oncogene 35: 691-701, 2015.

23. Carrillo AM, Hicks M, Khabele D and Eischen CM: Pharmacologically increasing Mdm2 inhibits DNA repair and cooperates with genotoxic agents to Kill p53-inactivated ovarian cancer cells. Mol Cancer Res 13: 1197-1205, 2015.

24. Dimri GP, Lee X, Basile G, Acosta M, Scott G, Roskelley C, Medrano EE, Linskens M, Rubelj I, Pereira-Smith O, et al: A biomarker that identifies senescent human cells in culture and in aging skin in vivo. Proc Natl Acad Sci USA 92: 9363-9367, 1995.

25. Schmitt CA: In vivo Complexities of Cellular Senescence in Tumor Development and Therapy. AACR Education Book, pp499-504, 2008.

26. Roninson IB: Tumor cellular senescence in cancer treatment. Cancer Res 63: 2705-2715, 2003

27. Erdmann J: Cancer's big sleep: Senescence may be potential target for cancer therapies. J Natl Cancer Inst 97: 89-91, 2005.

28. Cristofalo VJ and Pignolo RJ: Molecular markers of senescence in fibroblast-like cultures. Exp Gerontol 31: 111-123, 1996.

29. Herbig U, Jobling WA, Chen BP, Chen DJ and Sedivy JM: Telomere shortening triggers seneseence of human ceils through a pathway involving ATM, p53, and p21(CIPI), but not p16(INK4a). Mol Cell 14: 501-513, 2004.

30. Serrano M, Lin AW, McCurrach ME, Beach D and Lowe SW: Oncogenic ras provokes premature cell senescence associated with accumulation of p53 and p16INK4a. Cell 88: 593-602, 1997.

31. Sharpless NE and DePinho RA: Cancer: Crime and punishment. Nature 436: 636-637, 2005.

32. Collado M, Gil J, Efeyan A, Guerra C, Schuhmacher AJ, Barradas M, Benguría A, Zaballos A, Flores JM, Barbacid M, et al: Tumour biology: Senescence in premalignant turnouts. Nature 436: 642, 2005.

33. Elmore LW, Rehder CW, Di X, McChesney PA, Jackson-Cook CK, Gewirtz DA and Holt SE: Adriamycin-induced senescence in breast tumor cells involves functional p53 and telomere dysfunction. J Biol Chem 277: 35509-35515, 2002.

34. Fujiwara-Igarashi A, Goto-Koshino Y, Mochizuki H, Sato M, Fujino Y, Ohno K and Tsujimoto H: Inhibition of p16 tumor suppressor gene expression via promoter hypermethylation in canine lymphoid tumor cells. Res Vet Sci 97: 60-63, 2014.

35. Kamesaki S, Kamesaki H, Jorgensen TJ, Tanizawa A, Pommier Y and Cossman J: Bcl-2 protein inhibits etoposide-induced apoptosis through its effects on events subsequent to topoisomerase II-induced DNA strand breaks and their repair. Cancer Res 53: 4251-4256, 1993. 